\title{
A szófajjelölő képzők funkcionális vizsgálata
}

\section{A szófajjelölő képzőkről}

A leíró grammatikák a képzők jellemző tulajdonságaként tesznek említést arról, hogy a „képző lehet szófajtartó (halász), szófajváltó (zongorázik) és szófajjelölő (pattan)” (Keszler 2000: 308). A szófajjelölő képzők szinonimájaként a szakirodalomban többféle terminussal is találkozhatunk (pl. beillesztő képző, igésítő képző, honosító képző, adaptációs képző). Ezeket a terminusokat igyekeztem úgy osztályozni, hogy kirajzolódjanak a más-más funkcióval rendelkező, különféle szófajjelölő képzők közötti funkcionális különbségek. A csoportosítás egyik fö szempontjaként azt vettem figyelembe, milyen típusú tőhöz járulnak ezek az úgynevezett szófajjelölö képzők: (1) a kötött/fantom tövek után álló képzőket beillesztő képzőnek és (2) a jövevényszavakon (elsősorban jövevényigéken) előforduló képzőket pedig honosító (vagy adaptációs) képzőnek nevezem a továbbiakban.

\section{1. táblázat. A szófajjelölő képzők rendszere}

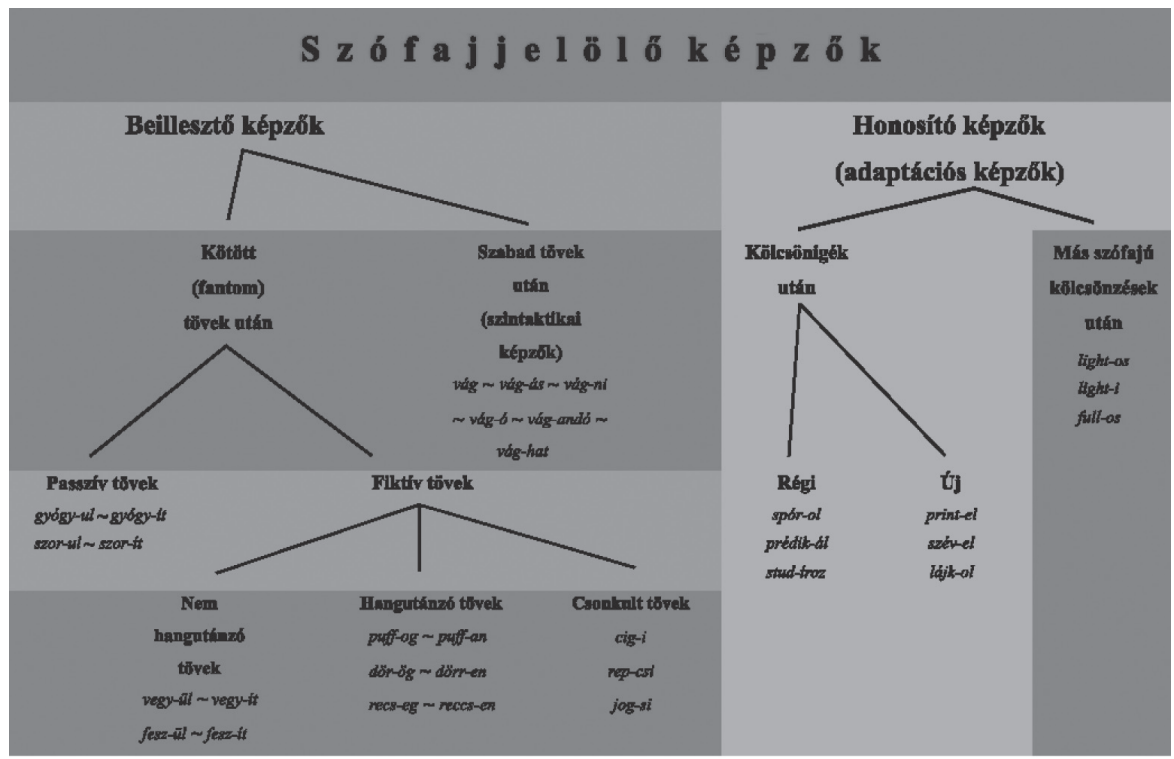

A szófajjelölő (igésítő, főnevesítő, melléknevesítő stb.) képzők nem tekinthetők tipikus képzöknek, hiszen nem a szó szoros értelmében vett képzés a funkciójuk, és nincs jelentésmódosító szerepük sem. A magyarban a szófajjelölő képzők túlnyomó többsége igésítő képző, tehát ezek a végződések elsősorban az ,igeiség” szófaji jellegét jelzik a szóalakon, a szó jelentéséhez nemigen járulnak hozzá.

Újabban néhány neologizmusban találkozhatunk a melléknévi szófajiságot nyomatékosító úgynevezett melléknevesítő képzővel is. Ilyenek például ang. light 
'könnyü' > m. light-os light-i (szleng) 'könnyü, nem elég jó', ang. full 'teljes' > m. full-os (szleng) 'tökéletes, minden szempontból megfelelő, jó' (pl. fullos autó, fullos csaj), ang. cool 'szuper, állati jó, menő' > cool-os/kúl-os 'jó, menő' (pl. kúlos buli), lat. sexualis 'nemi, nemhez tartozó'> m. szex-i (1965) 'nemileg izgató' > szexi-s, cigány raj 'vagány, menő, minőséget sugalló' (pl. raj csávó, raj séró) > m. raj-os 'ua.'.

A melléknevesítő képző alkalmazása nem új jelenség: a német schlecht 'rossz, silány, hitvány, értéktelen, aljas’ szó melléknévi jelentésben került a magyarba még a 15. században. Ma melléknévi jelentésben a melléknevesítő képzővel ellátott változat, a selejt-es forma él, a selejt fónévi jelentésűvé vált (vö. TESz 3: 512). Ugyancsak német jövevényszó a ma már jobbára csak a nyelvjárásokban élö fájin (vö. n. fein 'finom, kitünő'). Ebből alakult ki a fájintos származék (1878), amely az -s melléknévképzővel és egy - $t$ járulékhang betoldódásával jött létre (vö. Zaicz 2006: 196). A kölcsönzött lexémák hiába melléknévi jelentésüek, a nyelvhasználók feltehetően nem érzékelik szófajukat, ezért magyar melléknévképzőkkel $(-(V) s,-i)$ erősítik meg szófaji értéküket.

„Főnevesítő” képzőink nincsenek: az idegen nyelvekből átvett fönevek alaki beilleszkedése problémamentesnek tünik a magyarban. Ez egyrészt azzal magyarázható, hogy a grammatikai nem (sexus) fogalma ismeretlen a magyarban, másrészt azzal, hogy a magyarban a névszók körében nincs jellemző szóvégstruktúra, jellegzetes végső fonéma: a magyar nyelv története folyamán a névszók bármilyen végződésűek lehettek, tehát a névszói szófaj és végződése között nem fedezhető fel olyan összefüggés, mint például a latinban, az oroszban vagy az olaszban (szemben az igei szófajiságú lexémákkal, lásd később). Papp Ferenc statisztikai számításokon alapuló megállapítása szerint (Papp 1967, 1968) mind a mássalhangzós, mind a magánhangzós végü névszók száma egyaránt nagy. „Az ige és a névszó (illetőleg az ige és a többi szófaj) közti különbség ma abban nyilvánul meg a magyarban, hogy míg az igék csak meghatározott képzővel léphetnek a nyelvbe, addig a többi szófaj bármilyen végződésü lehet. Az a tény, hogy az igékkel ma velejár az igésítő képző, tehát a képzőre végződés, más szófajokkal viszont nem, azt jelenti, hogy az igésítő képzőre végződés és vele párhuzamosan ellentettje, a nem igésítő képzőre végződés egyre inkább a morfológiai információ szerepét, jelen esetben a szófajjelölés funkcióját láthatja el [...]. A kettő közül az igésítő képzőre végződés exponáltabb, dinamikusabb: egyértelműen igei szófajt jelöl. A nem igésítő képzős szó ezzel szemben - a szóvég felől nézve - csupán »nem-ige«: lehet névszó, de határozószó, viszonyszó vagy éppen indulatszó is. A szóvég igeközpontúságát, informatív szerepét kitünően bizonyítja a nyelvtörténet" (Kiss 1972: 307-8).

Míg a kölcsönfönevek általában könnyen képesek beilleszkedni a magyar nyelv morfológiai rendszerébe, addig egy magyar eredetű fónév alaki beilleszkedése valamely - főként a grammatikai nem kategóriájával rendelkező - indogermán nyelvbe korántsem ilyen egyszerü: a grammatikai nemmel rendelkező nyelvek minden jövevényfönevet (így a magyarból átvett föneveket is) grammatikai nemmel ruháznak fel - általában végződésük, illetőleg a rokon jelentésü szavak neme alapján -, vö. például m. huszár > n. der Husar (hímnemü) > sp. el húsar (hímnemü), m. gulyás $>$ n. der/das Gulasch (mássalhangzós végződése miatt hím- és semleges nemü egy- 
aránt lehet), m. kocsi > n. die Kutsche (nőnemü) > sp. el cohce (hímnemü), m. puszta > n. die Pußta (nőnemü) > sp. la puszta (nőnemü), m. szablya > n. der Säbel (hímnemü) $>$ sp. el sable (hímnemü) (a német példákat Kiss-Schlachter 1974-ből, a spanyol példákat Oszkó 1997-ből vettem). Az indoeurópai nyelvek között vannak olyanok, amelyekben van összefüggés a szófaj és a szó végződése között. A latinban, az újlatin és a szláv nyelvekben morfológiai kitevők, inflexiós markerek (végződések) is jelölik a lexéma szófaját és nemét. Az oroszban például az élettelen fönevek morfológiai tulajdonságai többé-kevésbé jól körvonalazhatók: a hímnemü főnevek alanyesete jelöletlen, zéró morféma (pl. стол- $\varnothing$, отец- $\varnothing$, товарищ- $\varnothing$ ), a nőnemüek - $a$-ra (pl. буква), я-ra (pl. деревня) vagy b-re (pl. дверь) végződnek, a semleges nem morfológiai jele pedig az -о (pl. окно), - $е$ (pl. море) és a -мя (pl. имя) végzödés. Ezek a fönévi végződések nemcsak a grammatikai nemet jelzik, hanem alapvetően meghatározzák a ragozási típust is. A magyar kölcsönszavak, átkerülve e nyelvek valamelyikébe, először gyakran - a grammatikai nemet is jelző - szófajjelölő (igésítő, főnevesítő, melléknevesítő) végződést kapnak, hogy ragozhatóvá váljanak az átvevő nyelv deklinációs és konjugációs rendszerében, vö. például $\mathrm{m}$. kocsi > szlovén kočia (nőnemű főnév), m. csont > szlovén čonta (nőnemü főnév) (Dudás 2016 alapján). A horvát nyelvben is sok mássalhangzóra végződő magyar főnevet toldanak meg egy - $a$ hanggal, így illesztve be öket a nőnemü - $a$ tövü fönevek deklinációjába, például forinta, faršanga, pistranga, bakanča: ,az - a hang hozzáadásának oka lehet az is, hogy a nyelv törekszik a szokatlan végződések megváltoztatására, saját hangrendszeréhez való igazítására" (Nyomárkay 1989: 306). A horvátban a magyar melléknevek is gyakran kapnak honosító képzőt, amely e lexémák ragozási rendszerbe való beillesztését szolgálja, például m. csonka $>$ h. čonkav, m. sánta $>$ h. šantav, m. kedves $>$ h. kedvast, m. kurta $>$ h. kurtast. A magyar igék pedig általában -iti, -ati és -ovati (infinitivusi) képzőkkel adaptálódnak a horvát nyelvbe, például m. bátorit $>$ h. batriti, m. morog $>$ h. morgovati, m. ment $>$ h. mentovati (Nyomárkay 1989: 306 alapján).

\section{A beillesztő képzők csoportja}

\section{A) Kötött/fantom tövekhez járuló beillesztő képzők}

\subsection{Passzív tó}

A passzív és fiktív töveket leíró szempontból általában egységesen kezeljük, a megkülönböztetés közöttük inkább történeti: (1) a passzív tő a nyelvtörténet valamely korábbi szakaszában még élt szabad formában, mára azonban kötötté vált, a toldalékkal együtt lexikalizálódott, (2) a fiktív tő viszont soha nem is létezett önálló tőként, hanem „tő” és „,toldalék” együtt keletkezett, többnyire analógiásan (vö. Kádár 2007: 45).

A passzív tövek különleges helyet foglalnak el a szóképzési rendszer egészén belül. T. Somogyi szófaji szempontból semlegesnek tekinti őket, hiszen szinkron keretek között csak származékaik helyezhetők el az igei csoportban (amelyek tehát 
nem illethetők sem a deverbális, sem a denominális jelzővel). Esetükben T. Somogyi a „depasszivális” minősítést javasolja (vö. T. Somogyi 1987: 34-5), ezt elsősorban a passzív tövek sajátos szófaji helyzete, az ebből következő transzformációs nehézségek indokolhatják. A passzív tövekhez is gyakran járuló - $U l$, -it, -Odik stb. képzők funkciója például - a passzív tő hatásaként, szófaji sajátosságaik következtében némiképpen eltér a (teljes) tőalapú képzésektől: legfőbb feladatuk a szófajiság adásában van, tehát beillesztő funkciót töltenek be.

Passzív tőként tekinthetünk a gyógyít gyógyul (aktív mediális) igepárban és bizonyos összetett szavakban fennmaradt gyógy- tőre, (pl. gyógy-szer, gyógy-fü) ennek ugyanis a régiségben feltehetőleg volt önálló alakja, nevezetesen a jog (régi nyelvi jóg) 'jó, jobb <kéz, szem>; jobb kéz'. A szó eleji $j>$ gy hangváltozás megfigyelhető például gyalog, gyere szavainkban. A szóbelseji $g$ a szó eleji gy hatására válhatott $g y$-vé. Eredeti jelentése, a 'javul, javít' jelentésszükülése eredményeként korlátozódik ma az egészségi állapot javulásának a kifejezésére. Hasonló jelentésfejlődés figyelhetô meg néhány rokon nyelvben is, vö. finn paras 'legjobb', parempi 'jobb'> para-, parantu- 'gyógyul', paranta- 'gyógyít' (vö. Zaicz 2006: 270-1). Ugyancsak passzív a tő a szorg-os $\sim$ szorg-alom lexémákban. Alapszavuk valaha létezett önálló tőként, mára azonban már kihalt a szorog 'igyekszik, siet, nyugtalanít' ige (v. Zaicz 2006: 805).

A szor-ul szor-it $\sim$ szor-os $\sim$ szor-ong szavak szor- töve ösi, finnugor kori szótő, ma már önállótlan, passzív tő. A finnugor alapalak *śors 'szoros; szorul' volt, amely igenévszó lehetett. Ebben az esetben szoros szavunk az alapszó névszói megfelelöjének melléknévképzős származéka, a szorit $\sim$ szorul szorong pedig igei folytatásának származékai (vö. Zaicz 2006: 805, vö. még ak-ad ak-aszt ag-gat, ap-ad ap-aszt,

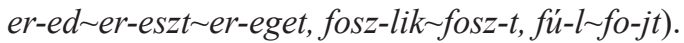

Érdekes a zsib-vásár összetett szó ismeretlen eredetü elötagjának története: a zsibtő önálló használatban ma már nem létezik, a régiségben azonban 'tolvaj' jelentésben élt önállóan. Az összetételekben az előtag 'limlom' értelművé vált, és ebben a jelentésében más összetételekben is szerepel, például zsib-árus, zsib-kalmár, zsibáru (vö. Zaicz 2006: 938).

A fej fönévi tő (eredetibb) fó alakváltozata is passzív tő jobbára: többnyire származékokban, illetve szóösszetételekben él tovább, például a fö fönévböl jött létre a fö-nök derivátum vagy a hét-fó, asztal-fö, fö-hajtás 'fejünknek a meghajtása', fökötö 'kendö', fó-fájás összetett szavak. A fö- főnévi tő melléknevesült jelentésben (félszóként/álszóként) szintén sok összetételben fordul elő (előtagként), például föiskola, fö-pincér, fó-kolompos, fö-név, fö-próba, fö-szerep, fö-nyeremény, fö-oltár. A melléknévi jelentés kialakulásának szemléleti alapja a fejnek mint a legfelül elhelyezkedő testrésznek a kitüntetett szerepe (vö. Zaicz 2006: 229). A fö szabad fönévi és melléknévi jelentése is ismert: fónévként például öt fö vett részt, négy före $\sim$ négy fö részére, fóbe lötte, józan fövel, melléknévként például legföbb ideje, hogy...

Az 'alsó rész' jelentésü ősi, uráli kori főnévi tő, az al- szerepel az al-om 'állatoknak fekhelyül leterített szalma' jelentésü származékban, illetve melléknévként összetett szavak előtagjává vált, vö. al-föld, al-peres, al-tiszt, al-orvos. Ez a tő sem szerepel ma önállóan (kivétel az al-ja valaminek 'alsó része'), passzív tővé vált. 


\subsection{Fiktív tő}

A passzív tövekkel ellentétben „fiktív tövü igének tekinthetjük mindazokat az igealakokat, amelyek képzőt (esetleg csak történeti elemzéssel kimutatható képzőt) hordoznak magukon, tövük azonban önálló lexémaként nem él, illetőleg valamely meghatározott korban - adataink tanúsága szerint - nem élt nyelvünkben" (Benkő 1984: 5). A fiktív tövü igék két oldalról, a tő és a képző felől közelíthetők meg: a fiktív tő olyan morfematikai fogalom (kötött morféma), amely csak a toldalékkal fennálló korrelációban létezik (uo. 17). E tövek között ugyan vannak - egyetlen képzővel lezárt - magányos fiktív tövek (pl. zok-og, tal-ál, in-t,áp-ol), de jelentékeny hányaduk nem magában, nem családtalanul létezik: a tőhöz általában nemcsak egyetlen képző, hanem több képző is csatlakozik (pl. gyakorító, mozzanatos, müveltető képzők, az azonos funkciójú -l és - $z$ képzők), igepárokat, igecsaládokat alkotva, ,s a képzőszembenállás a fiktív tövet teljesen világosan »kiugratja«: támad : támaszt : támogat stb.; repül : repít : repdes; apad : apaszt : apály; stb." (uo. 20). A valódi és a fiktív töveken lévő képzők között alaki és funkcionális azonosságok ismerhetők fel: a fiktív tövü igék végződésének legnagyobb része alapszavakból létrejött származékszavakon is feltünik, például tám-ad (tám-: fiktív tö) él-ed (él-: szabad tő); saj-og (saj-: fiktív tö) kavar-og, teker-eg (kavar-, teker-: szabad tövek); tal-ál (tal-: fiktív tö) dob-ál (dob-: szabad tő), amelyek ugyanazt a kezdő, gyakorító stb. jelentéstartalmat hordozzák, mint analóg társaik. A valódi képzéstől az különbözteti meg, hogy a valós képzett ige képzője a tő lexémaváltozatához képest betölti a deriválás funkcióját, a fiktív tövüé viszont nem. Emellett a fiktív tövekröl elmondható, hogy képzők nélkül nem vehetnének részt a toldalékolási rendszerben, hiszen a képzők által nyernek szófajiságot (vö. T. Somogyi 2000: 35). A fiktív tövü igékben tehát mind a tövek, mind a képzők sajátos fajtáival van dolgunk, amelyek a valódi származékszavak töveivel és képzőivel szembeállítva kapják meg különleges jellegüket.

A fiktív tövü igék lehetnek (1) nem onomatopoetikus és (2) onomatopoetikus fiktív tövek (e két igecsoport etimológiailag nem mindig választható el egyértelmüen egymástól, vö. Benkő 1984: 48), valamint (3) csonkolt tövek.

\subsubsection{Nem onomatopoetikus fiktív tövek}

A vegy-it vegy-ül igepár kikövetkeztetett vegy- töve szóelvonással keletkezett fiktív tő (az elegyít ige $v$-vel bővült változatából, illetve az igekötőnek érzett el- elhagyásával), amely sohasem volt önálló, szabad tő, csak származékokban és összetételek elötagjaként él, például vegy-i, vegy-ész; vegy-tan, vegy-ipar (vö. Zaicz 2006: 905).

A fesz-ül fesz-it fesz-es fesz-eget fesz-eng fesz-telen derivátumok (és továbbképzett változataik, pl.fesz-ül-et, fesz-ül-t-ség) ismeretlen eredetü alapszava is fiktív tö, önállóan nincs adatolva (vö. Zaicz 2006: 212).

Ilyen a sajog 'fáj' ige ismeretlen eredetü $s a j$ - töve is, amely önállóan nincs adatolva. Ez a tô talán azonos a saj-nál saj-nos lexémák hasonló alakú alapszavával. A saj-dit 'sajogni érzi valamijét' saj-dul 'a sajgó érzés hirtelen jelentkezik' igék is e tő származékai (vö. Zaicz 2006: 715). 
Bizonytalan eredetü fiktív töve van a moz-og moz-gat moz-dul moz-dit igéknek is. Ezek nyelvújításkori továbbképzett származékai a mozg-ékony és a mozgalom szavak (vö. Zaicz 2006: 551).

\subsubsection{Onomatopoetikus fiktív tövek}

Már Bárczi is felhívta a figyelmet arra, hogy nemcsak az igei jövevényszók esetében, hanem belső keletkezésủ szavak esetében is használunk beillesztő képzőket: „az igei átvételekben és a nyelv spontán igeteremtésében tapasztalható eljárás között párhuzam és kapcsolat van" (Bárczi 1948: 93); az igésítés módja azonos mindkét kategóriánál: a hangutánzó igék végződései beillesztik ezeket a szavakat a magyar igerendszerbe, kijelölik szófaji helyüket. A hangutánzó szavak jelentős számban fordulnak elő a szókészletben, rendszerint később is megörzik a hangalak és jelentés szoros kapcsolatát (idővel azonban ez a szoros kapcsolat meg is lazulhat: a puhul, reped, tapos igék egykori hangutánzó eredete ma már alig érezhetö, vö. Zsilinszky 2003: 177). Az onomatopoetikus szavak túlnyomó többsége igei alakulat (vö. BárcziBenkő-Berrár 1967: 309; Zsilinszky 2003: 177; Gerstner 2018: 261): ez a hangutánzás sajátos dinamizmusának az eredménye, illetve igei természetű tőre vallanak a deriválásban részt vevő képzők is. A fiktívtövüség a magyar onomatopoetikus igék erős jellemzője, ahogy az is, hogy ezek az igék mindig valamilyen képzőt mutatnak fel (képző nélküli hangutánzó igék a legnagyobb ritkaságok közé tartoznak, ilyen pl. a rop, vö. Bárczi 1948: 94 vagy a csesz és a csúszik, vö. TESz 1: 513/576), mégpedig jellemzően gyakorító, mozzanatos, müveltető és visszaható képzőket találunk rajtuk. Az onomatopoetikus jelleg különösen a „családosult”, többképzős, képzőszembenállásos származékok esetében állapítható meg egyértelmüen, például:

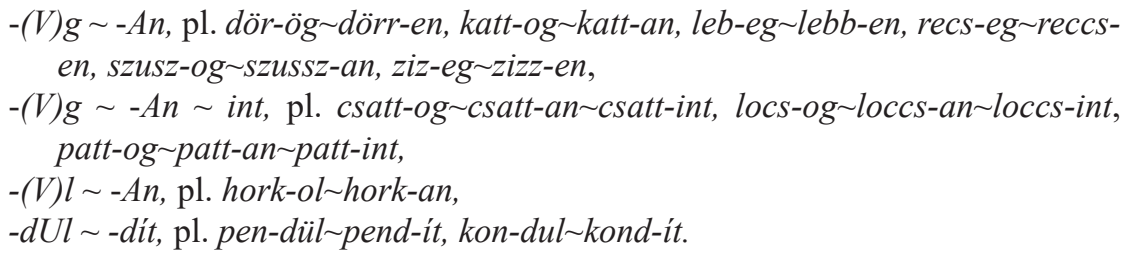

Az onomatopoetikus igék létrejöttének megítélése nem egyértelmü a szakirodalomban.

(1) Korábban a hangutánzást nem tekintették valódi képzésnek, leginkább „álképzés"-ként utaltak rá (vö. Benkő 1954, 1967: 310), azt feltételezve, hogy bennük egyszerre jött létre a hangkifejező előrész és a képzőszerü végződés, tehát „nem egy korábban már meglevő alapszóhoz járult később valamilyen képző" (Benkő 1967: 310). Vannak olyan igevégződések, amelyek tipikusan hangutánzó igék ,álképzői”, ilyen például az - $n$ mozzanatos képzö, a gyakorító jelentésü -kol/-kel/-köl -gol/gel/-göl (Benkö 1967: 311).

(2) Az újabb álláspont szerint (pl. Zsilinszky 2003) ezek az igék morfológiai szerkezetükben „megegyeznek a képzett szavakkal, hiszen végződéseik általában azonosak a többi (nem hangutánzó) ige képzőivel. Képzőtlen tövük azonban kez- 
detben önállóan nem létezik: a szóalak a már meglévő képzett igék mintájára jön létre" (Zsilinszky 2003: 177-8). Az expresszív képzés jellegzetessége, hogy a hangkifejező előrész, amely a megnyilatkozóban keltett hangélmény reprezentációjaként jelenik meg, tekinthető ugyan tőnek, de ez a tö nem önálló alapszó (nem elemezhető ki), ily módon tehát kapcsolatba hozható az úgynevezett fiktív tövü igékkel (vö. Balogh-Király 1976: 52, idézi Varga 2011: 90). A különféle hangokat utánzó hangsorok a hangutánzó előrész és a képző egyidejü összetapadásából tulajdonképpen a képzők segítségével váltak szófajisággal rendelkező valódi nyelvi elemmé a magyarban, tehát képző nélkül nem vehetnének részt a toldalékolási rendszerben. Mivel bennük a képző világosan felismerhető, disztribúciós elemzéssel kielemezhető a (fiktív) tő is. A tő kikövetkeztetését segíti, ha egy ige többféle képzős változatban előfordul, tehát egy (fiktív) tőhöz több képző is járul (pl. csatt-og csatt-an csattint), illetve ,[t]öbben az elemezhetőség elengedhetetlen kritériumának tartják, hogy ezek a képzők önálló előfordulású, azaz szabad tövekből is alkossanak származékokat. Tehát szerintük például a csattog, csattan lexémából kielemezhető csatt- tövet azért lehet elfogadni leíró szempontból is tőnek (természetesen fiktív tőnek), mivel létezik csavarog, tekereg, fogan lexéma is, melyekben a - $g$, illetöleg az - $n$ képző szabad tövekhez járul" (Keszler 2000: 64). Már Guttmann is úgy értelmezi a kérdést, hogy a hangutánzó igékben szegmentálható képzők ugyanúgy töltik be funkcióikat, mint a nem hangutánzó igék tövein, csakhogy a fiktív tövü igealakokban a képzö különböző funkciókban van jelen: amellett, hogy újabb lexikai egységet hoz létre, a szófajiság megteremtésében is szerepet játszik, valamint szintaktikai és jelentésbeli szempontból is jelentősége van. A hangélmény reprezentálására szolgáló tövek pedig morfológiai szempontból azonosíthatók a nem hangutánzó igék töveivel (Guttmann 1990: 18).

(3) Palágyi - a korábbi felfogásoktól eltérően, a kognitív nyelvtan (Langacker 2008) és a konnekcionista morfológiai modellek (Bybee 2010) hálózati megközelítését alkalmazva - azt hangsúlyozza, hogy a morfológiai kapcsolatok a szavak fonológiai és szemantikai hasonlósága révén alakulnak ki. Számára az onomatopoetikus igék azt példázzák, hogy a morfológiai szavak sem hagyományos értelemben vett toldalékolással jönnek létre, hanem e fonológiai és szemantikai hálózatból emergálódnak analógiásan. Hálózati értelemben tehát ezek az igék fonológiai és szemantikai csomópontok, töveik sem nem passzívak, sem nem fiktívek, aktivációs terjedéssel rendelkeznek (a puffog alak hálózatilag aktiválja nem csupán a durrog, hanem a puffan alakokat is), ,toldalékaik pedig annyiban vesznek részt az asszociációban, amennyiben hozzájárulnak a morfológiai szavak jelentéséhez, vagyis nincs lexikai egységtől független reprezentációjuk, sematikus jelentésüket a szóalakokból vonjuk el" (Palágyi 2019: 33).

\subsection{Csonkolt tövek után álló beillesztő képzők}

A felgyorsult élettempó, illetve a felpörgetett kommunikáció következtében a mai magyar nyelvhasználat egyik kétségtelenül legismertebb jelensége az édi, Meki, uncsi, cuki stb. típusba tartozó (kicsinyítő képzővel gyakran továbbképzett) rövidítések elterjedése és használata. A ,tündibündi nyelv"-nek is nevezett (Balázs 2001: 
223), rövidített, becéző, gügyögö formák ismertségéhez leginkább a sajátos stílust és nyelvezetet teremtő internet és a szóbeliséghez közel álló írott nyelvi formák (sms, chatprogramok, internetes fórumok, e-mail stb.) járultak hozzá. „A rövidítésekkel teletüzdelt nyelv eredetileg a szlengben, annak is főként az internetes és mobiltelefonos változatában és a diáknyelvben volt használatos, mostanra azonban már túllépte ezt a keretet, és a mindennapi kommunikáció részévé vált” (Schirm 2004: 153).

A szórövidülés valójában szócsonkítás/szócsonkulás eredménye, amely a lexémák bizonyos részleteinek elhagyásával történik, meglehetősen kiszámíthatatlanul (vö. Kiefer 1998: 226-7). A rövidített formáknak két fö típusa különíthető el:

1. A megrövidült (megcsonkított) alak tőszó marad, például kondi(ció), multi(nacionális), szitu(áció), gratula(lok), kösz(önöm), bio(lógiai), baci(llus), bá(csi), mini(atür), szoci(alista), irtó(zatos), rém(isztö), kösz(önet), tulaj(donos), akku(mulátor), szitu(áció), túl(ságos), labor(atórium), prof(esszor), hisz(en).

2. Nagyon tipikus, hogy a megrövidült (megcsonkított) alakok kicsinyítő képzővel bővülnek tovább. Ez a képzésforma meglehetősen ritka, hiszen más tőcsonkítással járó morfológiai mủveletet nem ismerünk a magyar alaktanban: ,„[...] a szabályos képzés szóalapú, márpedig a csonka tövek nem önálló szavak" (Kiefer 1998: 226-7).

A kicsinyítés valószínüleg minden nyelvben létező jelenség, amelynek megvalósítására a nyelvek különféle eszközöket dolgoztak ki. A magyar nyelv (hasonlóan az oroszhoz és a spanyolhoz) talán más nyelveknél is gyakrabban él a kicsinyítés lehetőségével (vö. Balázs 2011), amelyet a kicsinyítő (diminutív) képzők kiemelkedően nagy száma is mutat. A formai változatosság egyrészt abban érhető tetten, hogy a megrövidült (megcsonkított) alakok sokféle kicsinyítő képzőt vehetnek fel, másrészt abban, hogy - az egyébként jellemzően tulajdonfónévi (keresztnévi, családnévi) vagy közfönévi alapszavak mellett - különféle más (igei, melléknévi, mondatszói) szófajba tartozó csonka tövek is elláthatók kicsinyítő képzőkkel, például:

-i: $\quad$ fónevek: cig-i, csok-i, pör-i;

melléknevek: szimp-i, izg-i, dag-i, csil-i-vil-i;

interakciós mondatszók: Figy-i!, Kösz-i!, Bocs-i!;

-icsek: mondatszó: Rend-icsek!;

-ci: $\quad$ fönevek: $n a-c i, b o-c i$;

-csi: $\quad$ fönevek: pul-csi, rep-csi, Bal-csi;

melléknevek: fin-csi, un-csi, vil-csi;

igék: szer-csi-z(ik) 'szeret', láv-csi-z(ik) 'szeret', pusz-csi-z(ik) 'puszil', esz-csi-z(ik) 'eszik', für-csi-z(ik) 'fürdik', kösz-csi-z(ik) 'köszön valamit', bebasz-csi-z(ik) 'berúg';

-si: $\quad$ főnevek: akk-si, jog-si;

1 Az igei példákért köszönettel tartozom a KRE BTK Benda Kálmán Szakkollégiumában müködő Nyelvészeti Diákmühely érdeklődő hallgatóinak. 
-kó: főnevek: tet-kó, szer-kó, prot-kó;

melléknevek: tut-kó 'biztos';

-u: fónevek: ap-u, fiz-u;

-ó: $\quad$ fönevek: tes-ó, sap-ó, frig-ó;

mondatszó: Pusz-ó!;

-esz: főnevek: pál-esz 'pálinka', bocs-esz 'bocsánat', Kar-esz;

melléknevek: alk-esz 'alkoholista';

igék: vág-esz 'vágom, értem';

-nya: fönevek: sze-nya 'szendvics';

melléknevek: sze-nya 'szemét'.

A fenti példákban a köznevek csonka töve mellett megjelenő kicsinyítő képzők - megítélésem szerint - nem a megszokott kicsinyítő-becéző (kedveskedő, kedélyeskedő, bizalmaskodó stb.) vagy látszólagos becéző (ironikus, lebecsülö, elmarasztaló stb.) funkcióban és nem is vocativusi használatban (Peti, [...], anyuska, [...] stb., vö. Szücs: 2017), hanem sokkal inkább beillesztő funkcióban vannak jelen, így erősítve meg a véletlenszerüen (általában egy szótagra) lerövidített (megcsonkított) tő főnévi szófajiságát. Ebben a jelentésben manapság túlburjánzó tendenciát mutatnak, mégpedig a fentebb említett ,tündibündi” nyelvhasználatban, megteremtve a mostanában nagy népszerüségnek örvendő „szórövidülés és a szó továbbképzése” nevü (morfológián kívüli) szóalkotásmódot.

Önkéntelenül is felvetődik a kérdés: az (általában) egy szótagra „csonkított” tő (pl. cig < cigaretta, csok < csokoládé, ub < uborka) vajon miért bövül tovább kicsinyítő képzővel. Ez a kérdés újabb vizsgálódás és újabb tanulmány(ok) ötletét veti fel, én egyelőre csak egy előzetes, úgynevezett kísérleti tanulmány (ang. pilot study, pilot experiment) keretében, próbajelleggel végeztem adatgyüjtést, nevezetesen a - $g$ végződésü csonkolt tövek (pl. cig- $i<$ cigaretta, jog-si $<$ jogositvány, frig-ó $<$ fridzsider, dag- $i<$ dagadt) stb. kapcsán A magyar nyelv szóvégmutató szótárát (Papp 1976) használtam korpuszként, abból gyüjtöttem össze a -g-re végződő főnévi töveket, amelyeket szótagszám alapján csoportosítottam első lépésben.

2. táblázat. A -g-re végződő főnevek vizsgálata szótagszám alapján

\begin{tabular}{|c|c|c|c|c|c|c|c|c|}
\hline $\begin{array}{c}1 \\
\text { szótagú }\end{array}$ & $\begin{array}{c}2 \\
\text { szótagú }\end{array}$ & $\begin{array}{c}3 \\
\text { szótagú }\end{array}$ & $\begin{array}{c}4 \\
\text { szótagú }\end{array}$ & $\begin{array}{c}5 \\
\text { szótagú }\end{array}$ & $\begin{array}{c}6 \\
\text { szótagú }\end{array}$ & $\begin{array}{c}7 \\
\text { szótagú }\end{array}$ & $\begin{array}{c}8 \\
\text { szótagú } \\
\end{array}$ & Összesen \\
\hline 41 & 305 & 872 & 733 & 321 & 69 & 17 & 2 & 2360 \\
\hline $1,7 \%$ & $13 \%$ & $37 \%$ & $31 \%$ & $13,6 \%$ & $2,9 \%$ & $0,7 \%$ & $0,1 \%$ & $100 \%$ \\
\hline $\begin{array}{l}\text { pl. ág, } \\
\text { cég, } \\
\text { láng }\end{array}$ & $\begin{array}{c}\text { pl. } \\
\text { anyag, } \\
\text { virág, } \\
\text { üteg }\end{array}$ & $\begin{array}{l}\text { pl. gaz- } \\
\text { daság, } \\
\text { népes- } \\
\text { ség, } \\
\text { beszéd- } \\
\text { hang }\end{array}$ & $\begin{array}{l}\text { pl. tevé- } \\
\text { kenység, } \\
\text { bünbar- } \\
\text { lang, } \\
\text { hajlás- } \\
\text { szög }\end{array}$ & $\begin{array}{l}\text { pl. kü- } \\
\text { lönféle- } \\
\text { ség, } \\
\text { irásbeli- } \\
\text { ség, } \\
\text { állatbe- } \\
\text { tegség }\end{array}$ & $\begin{array}{c}\text { pl. meg- } \\
\text { elége- } \\
\text { dettség, } \\
\text { ideg- } \\
\text { kime- } \\
\text { rültség, } \\
\text { munkale- } \\
\text { hetöség }\end{array}$ & $\begin{array}{c}\text { pl. cse- } \\
\text { csemö- } \\
\text { halan- } \\
\text { dóság, } \\
\text { anyag- } \\
\text { takaré- } \\
\text { kosság, } \\
\text { sza- } \\
\text { vazat- } \\
\text { egyenlö- } \\
\text { ség }\end{array}$ & $\begin{array}{l}\text { terüle- } \\
\text { tenki- } \\
\text { vüliség, } \\
\text { iskola- } \\
\text { kötele- } \\
\text { zettség }\end{array}$ & \\
\hline
\end{tabular}


A táblázat adatai igazolják, hogy a -g-re (és prognosztizálhatóan bármely más fonémára) végződő fónevek nagy többsége nem egy szótagú: a magyarban a több szótagú főnevek (különösen a három és a négy szótagúak) vannak fölényben. Mindez nyelvünk agglutináló jellegéböl, a képzett és az összetett főnevek nagy számából következik elsődlegesen. Az egy szótagra csonkított tövek általában igyekeznek a tipikusabb szótagszámú többségi formához igazodni, vélhetően ezért bővülnek tovább képzővel. A vizsgált rövidített-továbbképzett példák mind két szótagúak, és beilleszthetők a - $g$ végü egy szótagú főnevek jellemző szótagstruktúrájába.

3. táblázat. A - $g$ végü egy szótagú főnevek jellemző szótagstruktúrája

\begin{tabular}{|c|c|c|c|c|}
\hline VC & CVC & CCVC & CVCC & CCVCC \\
\hline ág, ég, & $\begin{array}{c}\text { pl. mag, rag, tag, szag, } \\
\text { heg, jég, lég, } \\
\text { cig- } i, \\
\text { dag-i, } \\
\text { jog-si }\end{array}$ & $\begin{array}{c}\text { stég } \\
\text { frig-ó }\end{array}$ & $\begin{array}{c}\text { pl. gang, hang, rang, } \\
\text { láng, ing, }\end{array}$ & svung \\
\hline
\end{tabular}

\section{B) A szabad tövek után álló beillesztő képzők (szintaktikai képzők)}

Az új szótári jelentést nem adó, tisztán szintaktikai szerepü képzők is tekinthetők beillesztő képzőknek. Ezek az alapszó szótári jelentését általában nem, csak a derivátum bővíthetőségét, szintaktikai felhasználhatóságát változtat(hat)ják meg, például (fát) vág (fát) vágó: a képző nem változtatja meg az alapszó bővítményfelvevő képességét, átad (egy levelet) *átadatik (egy levelet): a képző megváltoztatja az alapszó szintaktikai környezetét (Károly példái 1970: 349). Beillesztő képző például az - $\dot{A} s$, a $-s \dot{A} g$, az -(t)At(ik), a - $h A t$, valamint az igenévképzők (-Ó, -t/-tt, -AndÓ, $-v A /-v A ́ n,-n i)$. Ezek a toldalékmorfémák - a prototipikus képzőkkel egybevetve sok tekintetben eltérően viselkednek. Szempontunkból két eltérés emelendő ki elsősorban: (1) míg a képzők termékenységét különböző fonológiai, morfológiai és szemantikai tényezők korlátozhatják, addig ezekre a toldalékokra az jellemző, hogy az adott szóosztályra jellemző toldalékok korlátozás nélkül járulhatnak a szóosztály minden tagjához; (2) míg a képzett szavak hajlamosak a lexikalizálódásra és a nyelvi egységgé válásra, addig a fenti képzőkkel megalkotott szóalakok jelentését mindig a részek jelentése motiválja, tehát morfoszemantikailag transzparensek.

$\mathrm{Az}$-Ás képző elsődleges szerepe a kategóriaváltás: ,az eredetileg az ige által dinamikus folyamatként, szekvenciálisan megragadott jelenségeket (pl. ugrik, söpör, gépel, varr) a fönév kategóriájába áthelyezve (pl. ugr-ás, söpr-és, gépel-és, varr-ás) - az alapesetben a térben létező dolgokra jellemző - időbeli stabilitásukban és egészükben ragadja meg” (Ladányi 2017: 613). A képző - néhány kivételtől eltekintve - tetszés szerinti igéhez járulhat, nem használható azonban a - $h A t$ toldalék után (vö. *tanulhat-ás, *sétál-hat-ás, de lát-hat-ás, lak-hat-ás, (meg)él-het-és). 
A -sÁg képző funkciója is elsősorban a szófajváltás: főként melléknevekből hoz létre elvont fóneveket, ,a tulajdonságot dologszerü, stabil jelenségként megragadva (pl. kemény-ség, puha-ság, vidám-ság, gyönyörü-ség) (Ladányi 2017: 613).

A -t(A)t(ik) képző funkciója, hogy (tárgyas) cselekvő igéből szenvedő jelentésü igét hoz létre. Passzív jelentésü igéket, passzív szerkezeteket akkor használunk, ha a cselekvőre (az ágensre) való utalás nélkül akarunk közölni valamit, tehát nem a cselekvő, hanem valaki (vagy valami) más szempontjából, perspektívájából akarjuk előadni, láttatni az eseményeket. Ilyenkor a cselekvés végrehajtóját háttérbe szorítjuk (lefokozzuk, defókuszáljuk), és az alany helyére - a cselekvés igazi végrehajtója (ágense) helyett - egy másik mondatrészt teszünk, mintegy kiszorítva a cselekvőt a nyelvtani alany pozíciójából, így a cselekvés az elszenvedő, a páciens nézőpontjából konceptualizálódik.

A - $h A t$ potencialitást jelölő toldalék besorolása mindmáig vita tárgyát képezi (lásd Kenesei 1996; Kiefer 2000), tulajdonságai ugyanis részben a képzőkre, részben az inflexiós toldalékokra jellemzőek. Ragszerü tulajdonsága, hogy korlátozás, megszorítás nélkül járulhat az igei szóosztály elemeihez, és - az inflexiós alakokra jellemző módon - sohasem lexikalizálódik.

$\mathrm{Az}$ igenevek többsége is szinte minden igetőből megalkotható (kivétel a befejezett melléknévi igenév és a beálló melléknévi igenév képzője, amely csak tranzítív igékhez járulhat produktívan), és nem hajlamos lexikalizálódásra. Az igenevek képzői tartalmas lexikai jelentéssel nem gazdagítják az igenevek jelentéstartalmát, feladatuk kizárólag a szófajváltás, az úgynevezett átmeneti szófajiság megteremtése. A derivátumok két szófaj tulajdonságait hordozzák egyszerre: ,,az igei tartalom az adott mondatrészszerepnek megfelelő szófaji-grammatikai formában jelenik meg, főnévi, melléknévi vagy határozószói jelleget ölt" (Lengyel 2000: 224).

\section{Honosító (adaptációs) képzők csoportjai}

A különböző nyelvekből származó (1) régi és (2) újabb igék honosításában szerepet játszó szófajjelölő képzőket a továbbiakban honosító (adaptációs) képzőknek nevezem: a beillesztő képzőkhöz hasonlóan ezek is általában igei szófajiságot adnak azoknak a jövevényeknek, amelyek eredeti formájukban nem képesek beilleszkedni nyelvünkbe.

A szókölcsönzést általában a megnevezés szükséglete hozza létre: ${ }^{2}$ mindez ,akkor indít el egy-egy beszélőt kölcsönzésre, amikor olyan új tárgyakkal, fogalmak-

2 A kizárólagosság azért nem érvényes, mert az is előfordulhat, hogy az átvevő nyelv rendszerében van megfelelő szó az adott tárgy, fogalom stb. kifejezésére, ennek ellenére sor kerül egy újabb szó átvételére. A szakirodalom az ilyen (felesleges) kölcsönzéseket „luxus jövevényszavak"-nak hívja; például így lépett a m. verö helyébe a szláv eredetủ kovács vagy a latin eredetủ rér helyébe először a (valószínüleg) ótörök süv, majd azt váltotta fel a német eredetủ sógor. Bárczi ebbe a csoportba sorolja a metró szót is (1974: 53), amely az átvétele idején fölösleges volt, mert jelentése megegyezett az 1896 óta ismert földalatti vasút szókapcsolat denotatív jelentésével (jóllehet mára jelentéskülönbség alakult ki a két kifejezés között: földalatti vasút 'kéregvasút', metró 'mélyvasút'). 
kal ismerkedik meg, amelyekre saját idiolektusában nem talál megfelelő kifejezést" (Kontra 1981: 12). A lexikális kölcsönzések, a szavak átvétele leggyakrabban tehát olyan új kultúra, új ismeretek, tárgyak, fogalmak átvételével függ össze, amelyek az átvevő nyelv kifejezéskészletéből hiányoznak, így az üres helyeket az átadó nyelv megfelelő szavai töltik ki (vö. Nyomárkay 2007: 106). Egy nép történetében minden (gazdasági, politikai, kulturális stb.) változás az idegen szavak nagy tömegének beáramlásával jár együtt, ezért aztán a nyelvek szókincsének tetemes része jövevényszó. „A jövevényszavak egész múltunk, történelmünk, kultúrtörténetünk, szomszédsági, gazdasági és kulturális kapcsolataink lenyomatát őrzik" (É. Kiss 2004: 79). A különféle korszakokban nyelvünkbe bekerült (iráni, törökségi, latin, szláv, német, olasz, francia stb.) jövevényszavakhoz a 20. századtól nagy számban csatlakoztak angol eredetü szavak, különösen a század utolsó harmadában, tudniillik a tudományos, technikai és kulturális újdonságok többsége Észak-Amerikából indult el világhódító útjára. Természetes, hogy az új tudományos-technikai vívmányokat, szórakoztatóipari termékeket először angol nevükön ismertük meg.

Az idegen eredetü lexémák - az átvevő nyelvek rendszerébe kerülve - hosszabbrövidebb ideig tartó nyelvi beépülési folyamaton mennek keresztül. A jövevényszavak beilleszkedése során helyettesítésröl (szubsztitúcióról) mind a fonémák, mind a morfémák szintjén beszélhetünk. A kölcsönszó-beépülés olyan folyamat, „melynek során az átvevő nyelvbe [...] átkerült átadó nyelvi elem úgy változtatja meg az átvevő nyelvben a hangalakját, alaki szerkezetét és jelentését, hogy az minél közelebb álljon a hozzá hasonló (pl. azonos szófajú, alaki szerkezetü, jelentéskörü stb.) átvevő nyelvi szavakéhoz, s így minél jobban belesimuljon az átvevő nyelvi diskurzusokba, ezzel pedig az átvevő nyelvi rendszerbe is" (Lanstyák 2012b: 7; WinterFroemel 2008: 159 alapján). A kölcsönszóvá válás folyamatában a szavak hangalakja szegmentális és szupraszegmentális változásokon megy át: „a kölcsönszóban eltérő hangok, megváltozott hangszekvenciák, különböző hangsúly-, hanglejtés- és időtartamviszonyok lehetnek" (Kontra 1981: 29). E folyamat eredményeként a kölcsönszó hangalakja nemegyszer hozzáidomul az átvevő nyelv hangrendszeréhez (ezt fonémahelyettesítésnek, (1) transzfonemizációnak nevezzük, vö. Filipović 1986: 79-81), alaki szempontból pedig gyakran olyan toldalékot vesz fel, amely lehetővé teszi az átvevő nyelvi közlésekbe való akadálytalan beillesztését (ezt morfémahelyettesítésnek, (2) transzmorfemizációnak nevezzük, vö. Filipović 1986: 123).

3.1. Transzfonemizációra (fonémahelyettesítésre) általában két esetben kerül sor: egyrészt akkor, ha az átvevő nyelv fonémarendszeréből hiányzik az adott fonéma, másrészt akkor, ha a fonéma megvan ugyan, ám a jövevényszóban lévő pozícióban (fonémaszekvenciában) nem fordul elö (Bárczi 1958: 46).

A fonológiai hanghelyettesítés során a beszélők az átadó nyelvi, az átvevő nyelvből hiányzó fonémát az átvevő nyelv valamely, hangképzés tekintetében rokon fonémájával helyettesítik, például a palatoveláris zöngétlen $c h[\chi]$ helyett a magyarban laringális $h$-t (képzésmód és hangszalagmüködés tekintetében azonos) vagy $k$-t (képzéshely és hangszalagmüködés tekintetében azonos) ejtenek, például szláv kuchnja $>\mathrm{m}$. kony$\boldsymbol{h} a$, n. Kelch $>$ m. kehely // n. Wachter $>$ m. bakter (vö. Lanstyák 2012b). Az átvevő nyelv fonémarendszerének üres helyei általában tehát nem fonémaátvétellel 
töltődnek ki, hanem például a nyelvben már létező allofonokkal helyettesítődnek (Kontra 1981: 14). A fonetikai hanghelyettesítés során az idegen eredetű fonémának a nyelvben szokásos hangszínárnyalatát ejtik a beszélők. A kölcsönszavak hangalakját kisebb-nagyobb mértékben mindig befolyásolja a beszélők első nyelvi artikulációs bázisa is (fonetikai hanghelyettesítéssel tehát általában kell számolni: ilyen esetben az érintett beszédhang fonológiai értéke nem változik meg az átadó nyelvihez viszonyítva, csupán az átvevő nyelvben szokásos hangszínárnyalatban illeszkedik be).

További hangváltozásokra lehet szükség a magyarban, ha például az átadó nyelv kölcsönzött szava vegyes hangrendü: a magyarban ilyenkor gyakran hangrendi kiegyenlítődés történik, például horvát milost 'kegyelem, könyörület, szeretet'> m. malaszt 'isteni kegyelem'.

A kölcsönszavak hangjai időtartambeli változásokon is átmehetnek: amennyiben a kölcsönszó például (rövid) $o$-ra végződik, azt mindig [hosszú] $o$-val vagy $a$-val helyettesítjük, erre azért van szükség, mert a köznyelvben és a legtöbb magyar nyelvjárásban a szó végén nem állhat rövid $o$ (néhány indulatszó kivételével), például fotó < fotográfia, infó < információ, mikró < mikrohullámú sütő, kiló < kilogram // m. csoda < szláv čudo, m. tészta < szláv těsto, vö. még gabona, maláta, nyoszolya, pólya, vitorla (vö. Kniezsa 1974).

Ha a szó peremén (elején vagy végén) mássalhangzó-torlódás van, azt gyakorta feloldjuk. A torlódások megszüntetése a szó elején történhet (a) az egyik mássalhangzó elhagyásával, például $\mathrm{n}$. Zwickel $>\mathrm{m}$. cikkely, (b) ejtéskönnyítő magánhangzóval (ún. elötéthanggal/protétikus hanggal), például szl. $d v o r z>u d v a r$, stols $>$ asztal, lat. schola > iskola, (c) a torlódó mássalhangzók közé iktatott bontóhanggal, például szl. bratb $>$ barát, lat. planta $>$ palánta, illetve (d) a torlódás első hangjaként álló $\beta$ vokalizálódásával, például szl. $\beta n u k a>$ unoka, szl. vlasi > olasz. A szóvégi mássalhangzó-torlódást általában egy magánhangzó betoldásával szüntetjük meg, például n. Lidl 'egy áruházlánc neve' $>$ m. Lidli.

A magyar nyelv angol kölcsönszavaiban leírt mássalhangzó-hosszabbodások (geminációk) is azt példázzák, hogy a kölcsönszavak hangalaki adaptációja az átvevő nyelv sajátos hangrendszeri tendenciái szerint alakul, például ang. weekend $>\mathrm{m}$. vikkend, ang. to tag 'beilleszt' > m. beteggel, ang. to photoshop > m. fotoshoppol.

Az adaptációban az idegen szavak hangsúlyát is gyakran áthelyezzük - a magyar hangsúlyozás szabályainak megfelelően - az első szótagra, például a pizzeria vagy az espresso szavakat is az első szótagjukon hangsúlyozzuk a harmadik, illetve a második helyett, tehát a magyarban érvényes hangsúlyminta szerint alakul a kölcsönszó hangsúlya. Ha az átadó nyelvben a szóhangsúly megszabja a hangsúlytalan szótagban lévő magánhangzók redukált (gyenge) ejtését (pl. angol, orosz), akkor ezek a redukáltan ejtett magánhangzó-realizációk a magyarban eredeti, hangsúlyos realizációjukhoz közeli hangértéket kapnak, például or. комбайн [kımbajn] > m. kombájn. A kombájn szó [o] hangja az orosz o fonéma első gyenge helyzetben levő realizációjának, az $[\Lambda]$ hangnak felel meg.

3.2. Transzmorfemizáció: a kölcsönszavak hangalaki adaptációja morfológiai szerkezetük adaptációjával (asszimilációjával/integrációjával) együtt zajlik le. Ennek során 
a kölcsönszó alaki szempontból olyan toldalékot vesz fel, amely lehetővé teszi az átvevő nyelvi közlésekbe történő akadálytalan beillesztését. A transzmorfemizációnak nevezett jelenség egyik legtipikusabb esete az, amikor az átadó nyelvnek (az átvevő nyelv rendszeréből hiányzó) kötött morfémája helyettesítődik egy, az átvevő nyelv rendszerébe illeszkedő kötött morfémával, például magyar képzővel látjuk el az idegen eredetű szót, így lehetővé válik a kölcsönige akadálytalan beillesztése az átvevő nyelvi közlésekbe, például m. spór-ol $<$ n. spar-en, m. gáz-ol $<$ szláv gaz-iti, m. kánt-ál < lat. cant-are.

A kölcsönfönév mindig az alakilag hozzá legközelebb álló magyar névszói csoportba és tőtípusba illeszkedik be, például a török alma a tővégi időtartam-változtató $-a /-e$ végü főnevekhez hasonlóan viselkedik toldalékok elött. A kölcsönszó beépülését több tény is bizonyítja, például az, ha az átvevő nyelvben jelentéstani szempontból az átadó nyelvinél specializáltabb denotatív jelentésben válik használatossá, például ang. to uninstall > m. '(számítógépes alkalmazást) töröl'. Gyakran fordul elö, hogy a jövevényszavaknak eredeti, az átvételkor ismert jelentéseik mellé új jelentések alakulnak ki, amelyek túlnyomórészt az adott nyelven belül lezajlott szemantikai változások eredményeként értékelhetők (pl. egér). A beépült szavakra továbbá jellemző lehet, hogy ,az eredeti szavakhoz hasonlóan tovább alakulhatnak az átvevő nyelvben: hangváltozásokon mehetnek át, képzett vagy összetett szavak alapjául szolgálhatnak stb.” (vö. Poplack-Sankkoff 1984: 100; idézi Lanstyák 2012b).

Nagy elörelépést jelent a honosításban a magyar fonetikus írásmódra való áttérés is, például lájkol, fájl, szerver, szoftver. Ezek a változások különösen érdekesek a tipológiailag különböző nyelvek esetében, mint például a flektáló angol (mint átadó nyelv) és az agglutináló magyar (mint átvevő nyelv) esetében, és az egész kérdéskör nagyon érdekes és tanulságos általános nyelvészeti szempontból is.

\subsection{A régi igei átvételek (elsősorban törökségi, latin, szláv, német stb. nyelvekből származnak)}

A honfoglalás előtt és a honfoglalás után nyelvünk szókincsébe került jövevényigék morfológiájában különbségek tapasztalhatók: a nyelvtörténet tanúsága szerint a honfoglalás előtti jövevényigék nem vettek fel semmilyen képzőt (puszta tőalakban honosodtak meg). A tőigék összegyüjtött listája alapján elmondható, hogy ezekböl relatíve kevés van (Papp számításai szerint 425, amely az igei állománynak mindössze 7,80\%-a, vö. Papp 1968: 35). A többi ige valamilyen képzőt mutat fel (ún. származékige), és számuk sokszorosa a tőigékének. Az etimológiával rendelkező tőigék között szembeszökő a finnugor (164 db) és magyar belső keletkezésü elemek (39) túlsúlya. Számban ezeket a törökségiből átvett tőigék (30 db) követik (vö. Papp 1968: 29-30).

Az etimológiai kutatások mai állása szerint a honfoglalás elött idegen eredetű igéket többnyire a (nyugati) ótörök nyelvekböl vettünk át. A török jövevényigék általában könnyen beilleszkedtek eredeti formájukban (beillesztő képző nélkül) a magyar igék szófaji osztályába. Arra a kérdésre, hogy az ótörökböl átvett igetövek vajon miért nem igényeltek beillesztő képzőt, Gombocz (1901) alapján próbálok 
válaszolni. Gombocznak igaza lehet abban, hogy sok nyelvben a szófaji kategóriák képzete általában bizonyos hangalakhoz kapcsolódik. Ha az átvett igető hangalakjához nem kapcsolódik igei jelentés az átvevő nyelvben (tehát az idegen ige hangalakja nem tud beilleszkedni az átvevő nyelv igéi közé), akkor ez a tö a többi ige hatására új morfológiai kitevőt kíván (Gombocz 1901: 223-4), és fordítva: ha az átvett igető hangalakja hasonló az átvevő nyelv valamely igecsoportjához, akkor igésítő képző nélkül is képes lehet a beilleszkedésre. Mivel a magyarban a szófaj és a szótári alak végződése között általában nincs olyan összefüggés, mint például a latin, az orosz vagy olasz nyelvben, amelyekben például a fónévi végződések alapvetően meghatározzák a főnevek grammatikai nemét és ragozási típusát. A magyarban nehezen tudnánk megmondani, milyen fonémákra végződhet alapalakban egy főnév vagy egy ige. A tőszókincs vizsgálatára szorítkozva azonban érdekes információkhoz juthatunk, ha a magyar nyelv szavait szóvégstruktúrájuk szerint hasonlítjuk össze. Ebből az egybevetésből megtudhatjuk, melyek a leggyakoribb (fönévi, igei, melléknévi stb.) tővégi fonémák, amelyekböl levonhatók bizonyos következtetések.

A vizsgálódások azt mutatják, hogy a magyar nyelv törökségi jövevényigéi gyakran végződnek -l és -r fonémára (pl. csavar, ír, gyül(ik), gyúr, gyür, seper, szán, szór, szökik, szür, tür), és mivel hasonló alakú, -l / -r fonémára végződő eredeti magyar tőige nagy számban található szókincsünkben is (pl. múl-, szúr-, tör-, fér-, facsar-, akar-, zavar - Gombocz példái 1901: 109), ezért a törökségi jövevényelemek könynyen be tudtak illeszkedni eredeti formájukban az ige szófaji osztályába. A fentebb említett gyakoriság számszerüsíthetővé vált Papp Ferencnek és munkatársainak köszönhetően (Papp 1967): az Értelmező szótárban talált 425 tőigével kapcsolatban kimutatták az egyes tővégződések gyakoriságát. Az alábbi táblázat jól mutatja, hogy a tőigék jellegzetes végső fonémája az - $l$ (amely az igék egyötödében szerepel záró elemként), és az -r fonéma is igen gyakori az igetövek végén (lásd 4. táblázat).

4. táblázat. A tőigék vizsgálata végződésük szerint (Papp 1967: 48 alapján)

\begin{tabular}{|c|c|c|c|c|}
\hline $\begin{array}{c}\text { Tővég } \\
\text { (a 0 morféma, } \\
\text { illetőleg az -ik } \\
\text { elött) }\end{array}$ & Mennyiség & $\begin{array}{c}\text { Az összes tőige } \\
\text { százalékában }\end{array}$ & Ebből: ikes & $\begin{array}{c}\text { Az összes ikes tö- } \\
\text { ige százalékában }\end{array}$ \\
\hline $\mathrm{a}$ & 1 & 0,24 & & \\
$\mathrm{~b}$ & 2 & 0,47 & & \\
$\mathrm{cs}$ & 2 & 0,47 & 1 & 1,30 \\
$\mathrm{~d}$ & 28 & 6,59 & & \\
$\mathrm{dz}$ & 2 & 0,47 & 2 & 2,60 \\
$\mathrm{f}$ & 1 & 0,24 & 1 & 1,30 \\
$\mathrm{~g}$ & 36 & 8,47 & & 2,60 \\
gy & 6 & 1,41 & 2 & 7,80 \\
$\mathrm{i}$ & 3 & 0,71 & 6 & 31,17 \\
$\mathrm{j}$ & 7 & 1,64 & 24 & 1,30 \\
\hline $\mathrm{k}$ & 11 & 2,59 & 1 & \\
\hline 1 & 97 & 22,82 & & \\
\hline $\mathrm{ly}$ & 1 & 0,24 & & \\
\hline
\end{tabular}




\begin{tabular}{|c|c|c|c|c|}
\hline $\begin{array}{c}\text { Tövég } \\
\text { (a 0 morféma, } \\
\text { illető̈leg az -ik } \\
\text { elött) }\end{array}$ & Mennyiség & $\begin{array}{c}\text { Az összes tőige } \\
\text { százalékában }\end{array}$ & Ebböl: ikes & $\begin{array}{c}\text { Az összes ikes tö- } \\
\text { ige százalékában }\end{array}$ \\
\hline $\mathrm{m}$ & 3 & 0,71 & & \\
$\mathrm{n}$ & 20 & 4,71 & 5 & 6,49 \\
ny & 4 & 0,94 & 1 & 1,30 \\
ó & 1 & 0,24 & & \\
ó & 4 & 0,94 & 2 & 2,60 \\
$\mathrm{p}$ & 14 & 3,29 & 4 & 5,19 \\
\hline $\mathrm{r}$ & 64 & 15,16 & 4 & 18,18 \\
\hline $\mathrm{s}$ & 11 & 2,59 & 14 & \\
$\mathrm{sz}$ & 24 & 5,65 & & 2,60 \\
$\mathrm{t}$ & 51 & 12,00 & 2 & 10,39 \\
ü & 1 & 0,24 & 8 & 100,01 \\
$\mathrm{v}$ & 6 & 1,41 & & \\
$\mathrm{x}$ & 25 & 5,88 & & \\
\hline Összesen & 425 & 100,02 & & \\
\hline
\end{tabular}

Később is kerülhettek be képző nélkül jövevényigék nyelvünkbe, de általában csak abban az esetben, ha végzödésük - véletlen alaki egybeesésnek köszönhetöen - megfelelt valamilyen produktív magyar igeképzőnek: ez esetben ezt a végződést a magyar nyelvérzék (tévedésből) képzőként értelmezte, az azonos végződésü igék (pl. deszká-z, példá-z, ruhá-z) analógiás hatására igének érezte, ennélfogva ezek újabb igeképzőt nem kaptak. Ilyen például a mára már elavult ábráz 'alakít, ábrázol' ige, amely a szláv eredetü obrazb 'alak, kép, mód' főnévből jött létre szófajváltással, tehát kizárólag végződésének köszönhetően igésült: ${ }^{3}$ végződése és a produktív $-(V) z$ igeképző véletlen alaki egybeesésnek köszönheti igei jelentését (vö. Bárczi 1948: 84; Kiss 1972: 303; Zaicz 2006: 3). A gyámol 'gyámolít' ige is a gyámol 'táplálás' főnévből keletkezett úgy, hogy a „nyelvérzék megtévedésével igének fogták fel” (TESz 1: 1119).

A magyar szókincsben először a honfoglalás után (az ómagyar kor folyamán) jelentek meg nagy számban olyan (német, szláv, latin stb.) jövevényigék, amelyek eredeti formájukban nem illeszkedtek be a magyar nyelv morfológiai rendszerébe, és amelyek honosításában kulcsszerepet kaptak bizonyos képzők, amelyek - a nyelvtörténeti adatok tanúsága szerint - a honfoglalást követően szinte minden igei átvételen megjelentek, így a honfoglalás után az igék alakilag is jelöltté váltak. ${ }^{4}$ Kiss Jenő kategorikusabban fogalmaz: „Jelen tudomásunk szerint nincs egyetlen olyan hon-

3 Az ilyen típusú igék között vannak olyanok, amelyekről nem bizonyítható, hogy valóban igei átvételek: lehet, hogy főnévként kerültek a magyarba, és csak később váltak igékké is, tudniillik szóvégi mássalhangzójukat a nyelvérzék képzőnek foghatta fel (vö. Bárczi 1948: 84).

${ }^{4}$ Bárczi két egészen kivételes (és bizonytalan) ellenpéldát említ: fék, mér (vö. 1948: 92). Ez érthetö, hiszen a nyelvi jelenségek általában nem egyöntetüen zajlanak le, egy régebbi nyelvállapot váratlan felbukkanása nem ritka jelenség. ,A helyzet tehát az, hogy míg a honfoglalás előtt az igei átvételek képzőtlenek, az újabb jövevényszó-rétegben ez az átvételi mód, ha nem is példátlan, de egészen kivételes" (Bárczi 1948: 92). 
foglalás utáni jövevényigénk sem, amely - képző és különféle analógiás hatások közrejátszása nélkül - a puszta idegen igető átvétele volna" (Kiss 1972: 303). A magyarban az idegen eredetü igék kötelező derivációs beillesztése tehát meglehetősen hosszú időre tekint vissza: az igék már több mint ezer éve képzők segítségével épülnek be a magyar szókészletbe, ennélfogva igéink egyik karakterisztikus morfológiai sajátosságává vált a képzőre végződés. Mivel az igeképzők kivétel nélkül mássalhangzóra végződnek, ezért aztán - a nagyszámú magán- és mássalhangzóra végződő névszókkal összehasonlítva - meglehetősen feltűnő, hogy az igei derivátumok között magánhangzóra végződő formát alig találunk, a néhány -i $(3 \mathrm{db}),-u ̈(1 \mathrm{db})$, -ó (1 db), -ö (4 db) végü ige kivételnek számít (pl. -í: rí, -ü: nyü, -ó: ró, -ő: szó), így aztán az igék és a névszók között kimutatható szóvégkülönbség fontos morfológiai információvá vált. A jövevényigék meghonosítására elsősorban az alábbi képzők álltak rendelkezésre:

az - $(V) l$ képző, például:

m. spór-ol $<\mathrm{n}$. spar-en,

$\mathrm{m}$. kóst-ol $<\mathrm{n}$. kost-en,

m. hód-ol $<\mathrm{n}$. huld-en,

m. gáz-ol < szláv gaz-iti,

m. abár-ol < szláv obar-iti (vö. még pár-ol);

az -ál képző, például:

m. prédik-ál < lat. praedicare,

m. konklud-ál < lat. concludere,

m. kánt-ál < lat. cantare,

$\mathrm{m}$. ping-ál $<$ lat. pingere,

m. aprehen-dál < lat. apprehendere (vö. még cirkál, citál, diktál, grasz-

szál, fundál, gusztál, prédikál, protestál, reformál, taksál), és

az -éroz/-iroz képző állt rendelkezésre, például:

m. stud-éroz / stud-íroz < < lat. studire (vö. még park-íroz, plakat-íroz, friz-íroz, fix-íroz, szek-íroz).

A tények (a nyelvi adatok) azonban nem mindig engedelmeskednek az elméletnek: továbbra is kérdés például az, hogy a fúr, szúr, gyúr stb. igék népes csoportja ellenére vajon miért kapott képzőt a magyarban a spór-ol (n. sparen) ige (holott az ótörök eredetű szór nem lett *szór-ol), vagy a szláv pariti-ból annak ellenére lett pár-ol, hogy a magyarban léteznek vár, zár stb. igék. Ez azért is lényeges kérdés, mert az igésítő képzők használata nemcsak az igei átvételekben mutatkozik meg, hanem a belső keletkezésű (onomatopoetikus) igék esetében is.

\subsection{A legújabb igei átvételek (többnyire angol nyelvi jövevényelemek, a 20. század utolsó harmadától)}

Mivel igéink túlnyomó többsége képzőre végződik (az ÉrtSz.-ban mindössze 425 tőige található, vö. Papp 1967: 45-52, 1968: 30), és mivel az új igéknek alakilag 
is be kell illeszkedniük az igei szófaji rendszerbe, ezért analógiás hatásra azokat a képzőket veszik fel, amelyek beilleszkedésük pillanatában a legproduktívabbak és leggyakoribbak. Ezzel magyarázható, hogy a magyar nyelvbe kerülő új igék (a belső keletkezésüek és a jövevények egyaránt) mindig valamilyen képzöt mutatnak fel. A magyarban kötelező a derivációs beillesztés (az ún. honosítás): csak a rendszerbe már igeként beillesztett elem ragozható, illetve képezhető tovább, tehát például a szken (to scan), cset (to chat), szkájp (to skype) stb. típusú idegen igetövekhez honosító képző nélkül sem igei személyragok (*szken-ek, *szken-sz, *szken / *cset-ek *cset-sz, *cset / *szkájp-ok, *szkájp-sz, *szkájp), sem más igeképző nem járulhat, tehát *szken-get, *cset-get, *szkájp-gat típusú derivátumok nem fordulhatnak elő. Igei személyragot vagy például frekventatív-duratív képzőt kizárólag a rendszerbe már igeként adaptált idegen elemek hozhatnak létre, például szkenn-el-ek, szkenn-el-sz, szkenn-el // szkenn-el-get, cset-el-get, szkájp-ol-gat (vö. Ladányi 2007: 101-13).

Az úgynevezett igésítés feladatát ma már csak néhány produktív képző képes ellátni. Mindez alighanem a produktív igeképzők számának a csökkenésével magyarázható. Hogy mikor melyik képző használatos, külön részletes vizsgálatot érdemelne. Az -ál képző több szótagú, mély vagy vegyes hangrendü igék beillesztésére használható produktívan (pl. export-ál, install-ál, konvert-ál), míg az egy szótagúak az - $(V) l$, a magas vagy vegyes hangrendü több szótagúak általában a - $(V) z$ képzöt veszik fel (pl. blog-ol, cset-el / twitter-ezik, wifi-zik). Honosító funkcióban rajtuk kívül más képző már nemigen jöhet számításba. Mivel az igevégződések egyre kevesebb számú típusra korlátozódnak, alaktanilag egyre világosabb különbség rajzolódik ki az igék és a névszók között (az igevégződések ezekre a képzőkre redukálódnak).

\subsection{Az angol nyelvből átvett legújabb kölcsönigék vizsgálata}

A magyar nyelvbe bekerült kölcsönigék nyelvünk morfológiai rendszerébe való beilleszkedését egy - az információtechnológia (IT) szókincsét bemutató - többnyelvü online szójegyzék adatain vizsgálom. ${ }^{5}$

A korpuszban található kölcsönzések alaktani beilleszkedését a gazdag morfológiájú igékre korlátozva vizsgáltam, kutatásom (egyelöre) más szófajokat nem érint. Szófaji megoszlás tekintetében a korpuszban egyébként a legtöbb jövevényszó fönév (226), számosság tekintetében a második helyen az igék állnak (86), ezek mellett a többi szófajnak csak igen kevés reprezentánsa akad, például melléknév (3: félkö-

5 Ezt az online szótárt az EU által támogatott „Hungarobox” nevű nemzetközi tanulási projektnek a partnerintézményei (a Károli Gáspár Református Egyetem, a Hamburgi Egyetem, a Tartui Egyetem és a Firenzei Egyetem) készítették 2013 és 2015 között. E projekt tagjaként magam is részt vettem az online szótár összeállításában. Vizsgálódásaimhoz elsősorban a „Hungarobox” projektben elkészült magyar-angol-észt-finn-német-olasz IT-szó-jegyzéket használtam adatbázisként (kiegészítve néhány érdekesnek tünő újabb adattal), és azt vizsgáltam, hogyan illeszkednek be a (zömmel) angol szókincsböl frissen átvett ITterminológia igealakjai a magyar nyelv morfológiai rendszerébe. 
vér, láthatatlan, olvasatlan) melléknévi igenév (6, pl. elérhető, elfoglalt, sorkizárt), határozószó (1: újra), határozói igenév (1: kijelentkezve).

A számítástechnika az 1990-es években vonult be életünkbe, és robbanásszerüen terjedt el nemcsak a szakemberek, hanem a laikus felhasználók körében is. A számítógépes szakemberek egymás közötti kommunikációjában a számítástechnika nemzetközi nyelvét (lingua francáját), az angolt használják. Az angol nyelvű terminológia észszerü mértékben történő magyarítása elsösorban a szakmabeliek és a laikus közönség közötti hatékony kommunikáció érdekében tünik kívánatosnak és szükségszerünek.

Az angol szavak és kifejezések beáramlását sokan kulturális gyarmatosításnak, veszélyes „angolszász nyelvi imperializmusnak” tekintik, féltve a magyar nyelvhasználatot az idegen szavak túltengésétől, ártalmasnak minősített divatjától. Mindannyiunk megnyugtatására idézem Lendvait, aki szerint ,a magyar eufórikusan habzsolja az amerikanizmusokat, de bölcsességének is jelét adja, mert egyúttal okosan válogat, rendez, magyarít" (Lendvai 1998: 29).

A korpusz vizsgálatából levonható következtetéseim igazolják Lendvai megállapítását: a magyar nyelv az új fogalmak megnevezésére a szóalkotás sokféle módját igénybe veszi, és csak az esetek viszonylag kis százalékában tartja meg az idegen (angol) elnevezést.

A korpuszban található 86 igei terminus közül 49-nek van magyar megfelelöje: áthelyez ( $<$ to move, to relocate), átnevez ( $<$ to rename), beállit ( $<$ to set), beilleszt $(<$ to paste), bejelöl ( $<$ to mark sy in a post), bekapcsol ( $<$ to turn on), belép ( $<$ to log in), beszúr ( $<$ to insert), betölt ( $<$ to load), bezár (< to close), csatlakozik ( $<$ to connect), csatol ( $<$ to attech), engedélyez ( $<$ to allow), fejleszt ( $<$ to develope), feltölt ( $<$ to upload), frissit ( $<$ to update / to reload), görget ( $<$ to scroll), helyreállit ( $<$ to restore), hirdet $(<$ to advertise), hivatkozik ( $<$ to link), hozzáad ( $<$ to add), hozzászól (< to comment), kalózkodik ( $<$ to pirate), kattint ( $<$ to click), keres ( $<$ to search), kijelöl ( $<$ to select), kivág $(<$ to cut), közzétesz ( $<$ to publish), küld ( $<$ to send), lefagy ( $<$ to freeze / to break down), lemerül ( $<$ to go dead), letilt ( $<$ to block), letölt ( $<$ to download), létrehoz ( $<$ to create), másol (< to copy), megbök (< to poke), megjelöl ( $<$ to mark), megnyit ( $<$ to open), megoszt ( $<$ to share / to create a post), mellékel ( $<$ to attach), nyomtat ( $<$ to print), ráir $(<$ to write to sy in chat), rákeres ( $<$ to search for), telepít ( $<$ to install), tetszikel ( $<$ to like), tölt ( $<$ to download), tömörít ( $<$ to compress), töröl (ti. számítógépes alkalmazást) (< to uninstall), továbbit ( $<$ to forward). Ezekben az esetekben jelentésbővülés zajlott le: ezek az igék csak az adott jelentéssel összekapcsolódva számítanak új szónak. Az új igei jelentések esetenként metaforikus/metonimikus jelentésátvitellel keletkeztek, például kalózkodik, lefagy, megbök.

Az angol nyelvü terminusok korpuszbeli száma 37, ezek a következők: archiv-ál, (be)boot-ol / (be)bútol, (be)lájk-ol, (be)link-el, (be)szkenn-el, betagg-el / beteg-gel, blog-ol, chat-el / cset-el, email-ezik / imél-ezik, export-ál, fészbuk-ol fészbok-ozik FB-zik, Google-izik / gugli-zik, import-ál, install-ál, (inter)net-ezik, (ki)poszt-ol, (ki)printel, kód-ol, komment-el, konvert-ál, photoshopp-ol / fotosopp-ol, (rá)klikkel, regisztr-ál, reklám-oz, skype-ol / szkájp-ol szkájp-ozik, sms-ezik susmus-ol, spam-el / szpem-el, spoiler-ezik, stream-el, selfi-zik / szelfi-zik, szörf-öl szörf-özik, 
troll-kodik, twitter-ezik, wifi-zik, youtube-ozik. Ezek között szép számban léteznek olyan terminusok, amelyekhez idöközben szinonim jelentésű magyar megfelelök társultak: (be)lájk-ol (be)teszikel, (be)link-el csatol, install-ál telepít, komment-el $\sim$ hozzászól, print-el $\sim$ nyomtat, (rá)klikk-el $\sim($ rá)kattint, reklám-oz $\sim$ hirdet, twitter-ezik csiripel.

A vizsgált adatok is arról tanúskodnak, hogy az idegen eredetü igék kötelező derivációs beillesztése nagyrészt az (egyébként denominális) - $(V) l$ (-ál) vagy - $(V) z$ honosító képzők segítségével történt. Ezek mellett a -kOdik képző szerepel még, igaz, csak egyetlen adatban (troll-kodik).

$\mathrm{Az}-(V) l$ és a $-(V) z$ (nemcsak denominális nomenképzőként, hanem) honosító képzőként is szinonim jelentésűek. A szóképzési jelentések azonossága ellenére sem mindig cserélhetők fel egymással, ugyanis a normatív nyelvhasználat a képzett alakokat rögzített lexikai egységként kezeli, és kizárólagosnak tartja. Bizonyos esetekben előfordulhat, hogy ugyanaz az alapszó mindkét képzőt felveszi (párhuzamos képzések), és a két alakzat között nincs jelentésbeli különbség, tehát az alakpárok szinonimái vagy kváziszinonimái egymásnak. A korpusz igéi között is találtan néhány ilyet, például fészbuk-ol fészbuk-ozik, szkájp-ol szkájp-ozik, sms-ezik susmus-ol, szörföl szörfözik. Prognosztizálható az a változás, hogy az egyik alak lassacskán kiszorítja majd a másikat (vö. pipál $\rightarrow$ pipáz(ik), vacsorál $\rightarrow$ vacsoráz(ik), ebédez(ik) $\rightarrow$ ebédel), vagy jelentésspecializáció lép fel közöttük, a két alakulat jelentése szétválik (vö. bérel bérez, kedvel kedvez, keresztel keresztez, magol magoz, okol okoz). A kölcsönzött igék gyakran fejlesztenek ki igekötős változatokat, például be-bootol, be-lájkol, be-szkennel, ki-printel, ki-posztol, rá-klikkel.

Az angol terminusok közül többet a forrásnyelv szerinti írásmód mellett már fonetikusan (azaz magyarul) írunk le, illetve fonetikusan is leírunk. Ez azt jelzi, hogy ezek az igék már többé-kevésbé beépültek a szaknyelvbe, jövevényelemekké váltak. Ilyenek például to boot up > (be)bútol, to like > (be)lájkol, to scan > (be)szkennel, to tag > beteggel, to chat > csetel, to photoshop > fotosoppol, to email > imélezik, to use Facebook $>$ fészbukol fészbukozik, to google $>$ guglizik, to post $>$ (ki)posztol, to click > (rá)klikkel, to registrate > regisztrál, to skype > szkájpol, to spam > szpemel, to make selfies $>$ szelfizik, to surf $>$ szörföl $\sim$ szörfözik.

\section{4. Összegzés}

A szófajjelölő képzők nem tekinthetők tipikus képzőnek, hiszen nem a szóképzés a legföbb funkciójuk, és jelentésmódosító szerepük sem hasonlítható össze a valódi képzésekkel. A tanulmány fő célja a szakirodalom által a szófajjelölő képzők szinonimáiként emlegetett terminusok (beillesztő képző, igésítő képző, honosító képzö, adaptációs képző) osztályozása úgy, hogy minél jobban kirajzolódjanak a más-más funkcióval rendelkezö, különféle szófajjelölő képzők közötti funkcionális különbségek. A különféle funkcióval rendelkező szófajjelölő képzők csoportosításakor egyrészt a tövek típusát (szabad vagy kötött tőhöz járulnak-e ezek a képzők), másrészt pedig a tövek eredetét (belső keletkezésűek-e vagy kölcsönzések) vettem figyelembe. 
A szabad és a kötött töveken lévő képzők között alaki és funkcionális azonosságok, illetve különbségek ismerhetök fel. A kötött tövü igék végződésének legnagyobb része alapszavakból létrejött származékszavakon is feltünik, például tám-ad (tám-: kötött tö) él-ed (él-: szabad tö); saj-og (saj-: kötött tö) kavar-og, teker-eg (kavar-, teker-: szabad tövek), amelyek ugyanazt a kezdő, gyakorító stb. jelentéstartalmat hordozzák, mint analóg társaik. A valódi képzéstől elsősorban az különbözteti meg őket, hogy a valós képzett ige képzője a tő lexémaváltozatához képest betölti a deriválás funkcióját, a kötött tövüé viszont nem. Emellett elmondható, hogy a kötött tövek képzők nélkül nem vehetnének részt a toldalékolási rendszerben, hiszen ezek éppen a beillesztő képzők által nyernek szófajiságot. A kötött tövü igékben tehát mind a tövek, mind a képzők sajátos fajtáival van dolgunk, amelyek a valódi származékszavak töveivel és képzőivel szembeállítva kapják meg különleges jellegüket.

A magyarban a szófajjelölö képzők túlnyomó többsége igésítő képző, tehát e végződések elsődleges funkciója az igeiség szófaji jellegének a jelzése, a szavak beillesztése a magyar igerendszerbe. Szófajjelölő képzőket főleg belső keletkezésü szavakon és idegen nyelvekből átvett kölcsönigéken találunk. A belső keletkezésű szavak közül az onomatopoetikus igék fö jellemzője, hogy mindig valamilyen képzőt mutatnak fel.

A régebbi és az újabb igei kölcsönzések feltünően különböznek abban, hogy kötelező derivációs beillesztésükben más-más típusú képzők vesznek részt. Ez pedig minden bizonnyal összefüggésben van a produktív magyar igeképzők számának a csökkenésével. Az úgynevezett igésítés feladatát ma már csak néhány (produktív és gyakori) képző képes ellátni. Ma többnyire az - $(V) l$, - $(V) z$ és az -ál képző használható produktívan (pl. export-ál, install-ál, konvert-ál), míg korábban más képzők is számításba jöhettek (pl. -kOdik, -Og, -An, -dos, -Ul, -it, -Ong, -izál).

\section{SZAKIRODALOM}

Balázs Géza 2001. Magyar nyelvstratégia. Magyar Tudományos Akadémia, Budapest.

Balogh Lajos - Király Lajos 1976. Az állathangutánzó igék, hívogatók és terelök Somogy megyei nyelvatlasza. Akadémiai Kiadó, Budapest.

Bárczi Géza 1948. Az igei átvételek kérdéséhez. Magyar Nyelv 44: 81-94.

Bárczi Géza 1958. A magyar szókincs eredete. Tankönyvkiadó, Budapest.

Bárczi Géza 1974. Nyelvmüvelésünk. Gondolat, Budapest.

Benkő Loránd 1954. Egy hangfestő igecsoport. Magyar Nyelv 50: 254-74.

Bárczi Géza - Benkő Loránd - Berrár Jolán 1967. A magyar nyelv története. Tankönyvkiadó, Budapest.

Benkő Loránd 1984. A magyar fiktiv (passziv) tövü igék. Akadémiai Kiadó, Budapest.

Bybee, Joan 2010. Language, Usage and Cognition. Cambridge Unicersity Press, Cambridge. https://doi.org/10.1017/CBO9780511750526

Dudás Előd 2016. A magyar jövevényszavak beilleszkedése a muravidéki szlovén irodalmi nyelv rendszerébe. Magyar Nyelv 112: 444-50. https://doi.org/10.18349/ MagyarNyelv.2016.4.444

Filipović, Rudolf 1986. Teorija jezika u kontaktu. Uvod u lingvistiku jezičnih dodira. JAZU - Školska knjiga, Zagreb. 
Gersner Károly 2018. Szókészlettörténet. In: Kiss-Pusztai (szerk.) 2018: 249-70.

Gombocz Zoltán 1901. Az igeszók átvételéről (Adalékok a nyelvkeveredéshez). Magyar Nyelvör 30: 105-9.

Guttmann Miklós 1990. A hangutánzó igék néhány alaktani, hangtani, jelentéstani sajátossága a muravidéki nemzetiségi magyarság nyelvében. In: Szabó Géza (szerk.): Nyelvtudomány. Magyar dialektológia. Szlavisztika. A Berzsenyi Dániel Tanárképző Főiskola Közleményei 6. Szombathely, 17-34.

Hadrovics László 1975. Szavak és szólások. Nyelvtudományi Értekezések 88. Akadémiai Kiadó, Budapest.

Hadrovics László 1989. A magyar nyelv kelet-közép-európai rokonsága. In: Balázs János (szerk.): Nyelvünk a Duna-tájon. Tankönyvkiadó, Budapest, 7-46.

Kádár Edit 2007. Alaktan és szófajtan. Egyetemi Mühely Kiadó - Bolyai Társaság, Kolozsvár.

Kenesei István 1996. Képző vagy nem képző? In: Terts István (szerk.): Nyelv, nyelvész, társadalom. Emlékkönyv Szépe György 65. születésnapjára barátaitól, kollégáitól, tanítványaitól. II. kötet. Janus Pannonius Tudományegyetem PSZM Projekt Programiroda, Pécs, 92-5.

Kiefer Ferenc 1998. Alaktan. In: É. Kiss Katalin - Kiefer Ferenc - Siptár Péter 1998. Új magyar nyelvtan. Osiris, Budapest, 187-289.

Kiefer Ferenc 2000. Helyzetkép a magyar nyelvtudományról. MTA Nyelvtudományi Intézet, Budapest.

Kiss Jenő 1972. A jövevényigék meghonosítása a finnugor nyelvekben (Észrevételek a finnugor nyelvek szófajjelölésének kérdéséhez). Nyelvtudományi Közlemények 74: 299-334.

Kiss Jenő - Schlachter Wolfgang 1974. A német nyelv magyar jövevényszavai és a der, die, das. Magyar Nyelv LXX: 458-62.

Kiss Jenő - Pusztai Ferenc (szerk.) 2003. Magyar nyelvtörténet. Osiris Kiadó, Budapest.

Kiss Jenő - Pusztai Ferenc (szerk.) 2018. A magyar nyelvtörténet kézikönyve. Tinta Könyvkiadó, Budapest.

É. Kiss Katalin 2004. Anyanyelvünk állapotáról. Osiris Kiadó, Budapest.

Kniezsa István 1974. A magyar nyelv szláv jövevényszavai. I-II. kötet. Akadémiai Kiadó, Budapest.

Kontra Miklós 1981. A nyelvek közötti kölcsönzés néhány kérdéséröl, különös tekintettel „elangolosodó” orvosi nyelvünkre. Nyelvtudományi Értekezések 109. Akadémiai Kiadó, Budapest.

Ladányi Mária 2007. Produktivitás és analógia a szóképzésben: elvek és esetek. Tinta Könyvkiadó, Budapest.

Ladányi Mária 2017. Alaktan. In: Tolcsvai Nagy Gábor (szerk.): Nyelvtan. Osiris Kiadó, Budapest, 501-660.

Langacker, Ronald W. 2008. Cognitive Grammar. A Basic Introduction. Oxford University Press, Oxford. https://doi.org/10.1093/acprof:oso/9780195331967.001.0001

Lanstyák István 2012a. Az északi magyar nyelvjárásokba bekerült szláv, illetve szlovák kölcsönszavak alaktani beépülése. In: Simon Szabolcs - Török Tamás (szerk.): A tudomány vonzásában. Köszöntö kötet a 70 éves Vörös Ottó tiszteletére. Selye János Egyetem Tanárképző Kar, Komárom. 99-109.

Lanstyák István 2012b. A kölcsönszavak beépülése a magyar nyelv szlovákiai változataiba 1. Fórum Társadalomtudományi Szemle 14/3: 3-26.

Lendvai Endre 1998. Gyógyír nyelvi önérzetünknek. Népszabadság, 1998. augusztus 8., 29.

Lengyel Klára 2000. Az igenevek. In: Keszler Borbála (szerk.): Magyar grammatika. Nemzeti Tankönyvkiadó, Budapest, 223-51. 
Nyomárkay István 1989. A magyar és szerbhorvát nyelv kapcsolata. In: Balázs János (szerk.): Nyelvünk a Duna-tájon. Tankönyvkiadó, Budapest, 291-347.

Nyomárkay István 2007. Rövid horvát és szerb nyelvtörténet. ELTE BTK Szláv Filológiai Tanszék, Budapest.

Oszkó Beatrix 1997. A spanyol nyelv magyar eredetủ szavai. In: Kiss Gábor - Zaicz Gábor (szerk.): Szavak-nevek-szótárak. Írások Kiss Lajos 75. születésnapjára. MTA Nyelvtudományi Intézete, Budapest, 267-9.

Palágyi László 2019. A magyar fönév kognitív morfológiai modellje. Doktori Disszertáció. Kézirat. ELTE BTK Nyelvtudományi Iskola, Budapest.

Papp Ferenc 1966. Megszólaltak a gépek. Magyar Nyelvör 90: 183-8.

Papp Ferenc 1967. Töigéink. Magyar Nyelvör 91: 45-52.

Papp Ferenc 1968. Szófaj és végződés. Magyar Nyelvör 92: 29-37.

Papp Ferenc 1976. A magyar nyelv szóvégmutató szótára. Akadémiai Kiadó, Budapest.

Poplack, Shana - Sankoff, David 1984. Borrowing: the synchrony of integration. Linguistics 22: 99-135. https://doi.org/10.1515/ling.1984.22.1.99

Schirm Anita 2004. Napjaink nyelvi változásai. Új nyelvi jelenségek a magyarban. In: Balázs Géza - Grétsy László (szerk.): Új jelenségek a magyar nyelvben. Válogatás a Nemzeti Kulturális Örökség Minisztériuma anyanyelvi pályázataiból. Nemzeti Kulturális Örökség Minisztériuma, Budapest, 147-67.

T. Somogyi Magda 1987. A passziv igetövek leiró vizsgálata a magyarban. Nyelvtudományi Értekezések 125. Akadémiai Kiadó, Budapest.

T. Somogyi Magda 2000. Toldalékrendszerezésünk vitás kérdései. Tinta Könyvkiadó, Budapest.

Szücs Tibor 2017. A kicsinyítés-becézés szemantikai-pragmatikai funkciói és nyelvtani formái. THL2: A magyar nyelv és kultúra tanitásának szakfolyóirata 2017/1-2: 145-57.

TESz I-II-III. = Benkő Loránd (föszerk.) A magyar nyelv történeti-etimológiai szótára. 1967/1970/1976. Akadémiai Kiadó, Budapest.

Varga Mónika 2011. Hangutánzó igék morfológiai vizsgálata. Magyar Nyelvjárások XLIX: 87-104.

Winter-Froemel, Esme 2008. Studying loanwords and loanword integration. Two criteria of conformity. Newcastle Working Papers in Linguistics 14: 156-76.

Zaicz Gábor (fószerk.) 2006. Etimológiai szótár. Magyar szavak és toldalékok eredete. Tinta Könyvkiadó, Budapest.

Zsilinszky Éva 2003. Szókészlettörténet. In: Kiss - Pusztai (szerk.) 2003: 372-92.

\section{H. Varga Márta}

KRE BTK Magyar Nyelvtudományi Tanszék https://orcid.org/0000-0002-2203-3853

\section{SUMMARY}

H. Varga, Márta

\section{A functional study of derivational suffixes indicating parts of speech}

One of the aims of this paper is to classify the terms occurring in the linguistic literature as synonyms for 'derivational suffixes indicating parts of speech' (suffix of integration, 
verbalizing suffix, nativizing suffix, adaptational suffix) in order to highlight the functional differences across the various suffixes indicating parts of speech. In classifying suffixes of diverse functions, the author takes stem types into consideration (whether the suffixes concerned are attached to free or to bound stems) on the one hand, and the origin of the stems (whether they are native or borrowed) on the other.

Another aim of the paper is to study the integration of borrowed verbs into the grammatical (phonological, morphological, and syntactic) system of Hungarian. Pre-conquest and postconquest verbal borrowings are strikingly different in whether they involve a derivational suffix of nativization or not, and also in the types of derivational suffixes indicating verbality that participate in the obligatory derivational integration of borrowed verbs.

Keywords: functions of derivational suffixes, derivational suffix indicating part of speech, derivational suffix of integration, derivational suffix of nativization, obligatory derivational integration.

\section{Az ellentétes mellérendelésről 16-17. századi bibliafordítások nyomán: variáció és változás}

\section{Bevezetés}

Az alábbi tanulmány az ellentétes mellérendelő mondatszerkezetek funkcionális variációjának néhány aspektusát mutatja be 16-17. századi bibliafordítások összevető elemzésével. Az egyes szöveghelyeket a következő fordítások alapján vetettem össze: Jordánszky-kódex (1519 k.), a vizsolyi biblia (1590) és Káldi György (1626) fordítása, valamint az újszövetségi részeknél tekintetbe vettem Sylvester János fordítását (1541).

A korszakra jellemző mondattörténeti változások a mellérendelés esetében elsősorban a kapcsolóelemek rendszerének gazdagodásával, elsődlegesen a kötőszókészlet bővülésével kapcsolatosak, magának a struktúrának az alakulását azonban ez nem befolyásolja (vö. Haader 2018: 218-20). A pragmatikai szempontok miatt a funkcionális variáció (szinonímia) vizsgálata ilyen esetekben is indokolt, mivel a mondattan terén számos választási lehetőség áll a megnyilatkozó rendelkezésére (Dömötör 2003: 450-1; Haader 2001: 367, 2004: 465-6). Ezáltal az egyéni nyelvhasználatok eltérhetnek a korszakra jellemzőnek tartott állapottól - az egyes szerzők (esetünkben fordítók) nyelvi választásait társadalmi, kulturális beágyazottságuk befolyásolja (vö. Haader 2003: 687).

A bibliafordítások ideálisak a funkcionális szinonímia vizsgálatához, mivel a referenciális tartalom eredendően többé-kevésbé azonos, ugyanakkor a megformálásban többféle szerkezeti lehetőség kínálkozik (Haader 2001: 366-7, 2004: 464-5). A biblikus szövegekre ráadásul az arányokat tekintve átlagon felüli számú mellérendelö kötőszós szerkezet használata jellemző - ez fordítási sajátosságnak (latinnal közvetített hebraizmusnak) tekinthető, ugyanakkor nem kizárt, hogy stíluseszköz a magyarban: erőteljes tagoló hatásával ünnepélyességet kifejezve (akár a szóbeli elbeszélő próza

\footnotetext{
* A tanulmány az MTA Nyelvtudományi Intézetben zajló 116217 számú OTKA-projektum (Versengő szerkezetek a középmagyar élőnyelvben: változók elemzésén alapuló megközelítés) támogatásával készült.
} 